\title{
The Empirical Studies of Multilateral Exchange Rate Models in Taiwan
}

\author{
Kuowei Chou (Corresponding author) \\ School of Economics, Fo Guang University \\ 160 Linwei Road, Jiaosi, Yilan 26247, Taiwan
}

Tel: 886-3-987-1000 ext $23517 \quad$ E-mail: Kwchou@mail.fgu.edu.tw

\author{
Pochun Lin \\ School of International Business, National Cheng-chi University \\ 64 Sec. 2 ZhiNan Road, Wenshan, Taipei 116, Taiwan \\ Tel: 886-2-2939-8033 E-mail: 94351501@nccu.edu.tw
}

\author{
Received: June 10, 2011 \\ Accepted: July 25, 2011 \\ Published: November 1, 2011 \\ doi:10.5539/ijef.v3n6p254 \\ URL: http://dx.doi.org/10.5539/ ijef.v3n6p254
}

\begin{abstract}
Theoretically, changes in macroeconomic fundamentals are reflected in the fluctuations of exchange rates. However, the relationship between these two variables was not clearly demonstrated when using the Taiwan-U.S. bilateral exchange rate as an example. Therefore, this study researches the cointegration relationship between exchange rate and fundamental variables from the angle of the multilateral exchange rate. The researchers use this process to verify the empirical reliability of applying the exchange rate model to a small open economy such as Taiwan. This study also uses the Granger causality test to strengthen the argument of this study. The results showed that the multilateral exchange rate could provide more comprehensive information and enhance the explanatory power of the traditional exchange rate model when applied to empirical research. The multilateral exchange rate can also assist researchers in interpreting the interdependent relationships between Taiwan and its major trade rivals.
\end{abstract}

Keywords: Bilateral exchange rate, Multilateral exchange rate, Cointegration, Granger-causality test

\section{Introduction}

The lack of empirical correlation between the exchange rate and macroeconomic fundamental variables has long been a puzzle in international finance. In theory, the exchange rate is determined by fundamental variables such as monetary supply, output, interest rate and price levels. However, most empirical data show that the exchange rates seem to follow random walks. Therefore, it is difficult to explain the movement of exchange rates using fundamental variables. For instance, Meese and Rogoff $(1983 a, b)$ used data in the 1970s to measure several exchange rate models with out-of-sample forecasts. They discovered that out-of-sample forecasts cannot beat the random walks in interpreting the fluctuation of exchange rates. Although some studies showed that in the long run, there is consistency in the movement of exchange rates with the fundamentals (for example, Chinn and Mess, 1995; Mark, 1995; Mark and Sul, 2001), it is generally believed that exchange rates are unpredictable, especially in the short run. As a result, no matter what form a theoretical model of exchange rates is, its feasibility has always been disputed in empirical studies.

Previous related studies yielded the following results. Empirical studies in the 1990s (for example, MacDonald and Taylor, 1993; McNown and Wallace, 1994; Moosa, 1994) found that when dealing with non-stationary data in econometric analysis, theoretical exchange rate models are still an effective framework for analyzing exchange rate fluctuations. MacDonald and Taylor (1993) proved that there is long-term equilibrium in exchange rate models, and that out-of-sample forecast outperforms the random walks in the long run.

Recently, Husted and MacDonald (1999) and Chinn (2000a, b) found a relationship between exchange rate fluctuations and monetary supply, interest rate, and output among a sample of East Asian countries. Baharumshah et al. (2010) applied cointegration analysis to find equilibrium between monetary variables and exchange rates. However, Cheung et al. (2002) pointed out that even though the long-term fluctuation of exchange rates can be predicted by the fundamental variables, it does not imply that all theoretical relationships in exchange rate models can be proved empirically. They also believe that no model can beat the random walks in the explanation of exchange rate fluctuations. 
Regarding the relationship between exchange rates and the fundamentals, Engel and West $(2004,2005)$ proposed another view based on the asset-pricing model. They pointed out that if the exchange rate can be expressed as a linear combination of the discounted value of current and expected future fundamental variables, as long as one or more influential variables have unit root and the discount factor is near 1, then the exchange rate will follow the random walks. In other words, the unstable characteristics of exchange rates can be interpreted by the asset-pricing exchange rate model. Short-term fluctuations of exchange rates might result from expected future changes. As a result, Engel and West $(2004,2005)$ believe that exchange rate fluctuations can help predict changes in the fundamentals (but not vice versa).

In view of this, Chou and Tseng (2008) extended the ideas of Engel and West $(2004,2005)$ in studying fundamental variables that are normally applied to determine the exchange rate model. Applying characteristics of the asset-pricing exchange rate model, they targeted Taiwan and six other Asia-Pacific countries to study the present value of exchange rates between their currencies and US dollars and to predict the performance of the fundamentals. They found evidence supporting the present-value form of exchange rates and fundamental variables in most countries. However, they could not find the correlation between exchange rates and the fundamentals in Taiwan. This highlights that the Taiwan-U.S. exchange rate is volatile and unpredictable. Therefore, they believe that the Taiwan-US exchange rate might be dominated by other factors that cannot be explained.

In recent years, the proportion of Taiwan-U.S. trade has slowed. According to Krugman and Obstfeld (2009), exchange rates signify the exchange ratio of currencies between different countries and to some extent reflects the relative economic conditions and policies between countries. If the countries have a higher dependency, exchange rate fluctuations will more obviously reflect changes in economic conditions. Thus, a decrease in the trade volume between Taiwan and the U.S. implies that the Taiwan-U.S. bilateral exchange rate alone is not comprehensive enough to serve as a reference. This is also the reason why some related studies cannot reach a conclusive result. Hence, we use the proportion of bilateral trade of Taiwan with its major trading partners to measure mutual dependency in the construction of a nominal effective exchange rate (NEER), and apply it to study the relationship between the exchange rate and market fundamentals.

As for the empirical method, we applied cointegration analysis and the Granger causality tests to study the long-term equilibrium and short-term fluctuations between exchange rates and the fundamentals. Empirical results showed that when considering the Taiwan-U.S. bilateral exchange rate model, it is hard to find a correlation between exchange rates and fundamentals. However, as the number of countries in the currency basket increased and a more comprehensive multilateral exchange rate was constructed, we were able to not only find cointegration relationships between exchange rates and fundamentals, but also verify the empirical reliability of the exchange rate models. In the short-term, the fluctuations of exchange rates significantly cause changes in the fundamentals; it supports the asset-pricing characteristics between exchange rates and fundamentals. Our results show that the multilateral exchange rate provides more comprehensive information and improves the explanatory power of traditional exchange rate models. It also helps explain the correlation between the macroeconomics of Taiwan and other countries.

The following is the structure of this paper. In section 2, we explore a nation's trade dependency, the measure of multilateral exchange rates, and compare it with traditional bilateral exchange rates. Based on the money-income model and Taylor rule model, we derive the domestic and foreign fundamentals that can dominate the exchange rates in Section 3. Section 4 presents the relevant empirical results. Section 5 is the conclusion.

\section{Trade dependency and multilateral exchange rate}

In recent years, the proportion of Taiwan-U.S. trade is gradually slowing. Using the Taiwan-U.S. exchange rate as the only measure for our fundamentals seems insufficient for research because it ignores the effects of changes in the trade structure to the economy (Tseng, 2007). Howitt (1986) also indicates that instead of a bilateral exchange rate, multilateral exchange rates provide more information for establishing a domestic monetary policy. As a result, we compile the nominal effective exchange rate (also called the weighted average exchange rate) to describe the fundamentals of Taiwan and its major trade partners, the rate effectively reflects the link of economic conditions among them.

Internationally, the International Monetary Fund (IMF) and some countries' central banks use the nominal effective exchange rate index to reflect the relationship of one country's exchange rate with major international currencies. There are no standard rules for constructing an effective exchange rate. For example, the U.S. Federal Reserve Board (Fed) and the European Central Bank (ECB) distinguish between major and secondary currency baskets based on the importance or special characteristics of trade partners. Regarding the weight of each country's currency in the basket, the Bank of Japan (BOJ) adopts export weight using the unilateral trading concept, while the Fed, 
ECB, and IMB adopt bilateral trade weights and third-market export weight. The weight for each trading partner is adjusted every five years (ECB) or every year (Fed and BOJ) (for more on how the above institutions compile the nominal effective exchange rate, please see Chen, 2006).

In terms of domestic studies, Tsaur et al. (2002) took 1995 as the base period and adopted a fixed weight to compile the real effective exchange rate index based on 18 trading partners of Taiwan. Tseng (2007) adopted the floating weight model, and compiled the real effective exchange rates from various baskets of currencies between 1995 and 2006. Tseng and Tsaur (2008) further discussed two key issues in the compiling of the real effective exchange rate indexm, the choice of weight and currency baskets.

Usually, only major trading partners are included in calculating the effective exchange rate. Rhomberg (1976) proposed seven kinds of weights, which include the bilateral trade weight, the export trade weight, the import trade weight, the third market trade weight, the average export weight, the average trade weight, and the double weighted average. These weights were used to calculate the weighted average of bilateral exchange rates between Taiwan and its major trading partners. Since the sum of exports and imports can directly reflect the trade intensity between Taiwan and a specific trade partner, this study calculated the weight based on the bilateral trade amounts after the countries in the currency basket were selected and then adjusted the weight of each period to compute the multilateral exchange rate. In the following study, we begin with the Taiwan-U.S. exchange rate to discuss the correlation between the theory of Taiwan's bilateral exchange rate model and empirical data. Then we extend it to a multilateral exchange rate. By dividing Taiwan's top 16 trade partners into three currency baskets, we use these currency baskets to test the feasibility of the multilateral exchange rate model (see Section 4).

\section{The nominal exchange rate model}

In this section, we determine the fundamentals for exchange rates according to the money-income model and Taylor rule. In the model, we define Taiwan as the home country, $s_{t}$ is the natural log value of nominal exchange rate, where the exchange rate is the New Taiwan dollars value of a unit of foreign currency (for example, the U.S. exchange rate is the New Taiwan dollars value per U.S. dollar).

\subsection{Money-income model}

Assume the money market relationship of the home country is as follows (see Engel and West, 2004, 2005; Chou and Tseng, 2008):

$$
m_{t}=p_{t}+\gamma_{t}-\alpha i_{t}+v_{m t}(1)
$$

Where $m_{t}$ is the natural log value of home country money supply; $p_{t}$ is the natural log value of home country's price level; $i_{t}$ is the interest rate of the home country; $y_{t}$ is the natural $\log$ value of home country's output; and $v_{m t}$ is the random shock of the home country's money demand. $\gamma$ is the income elasticity of money demand; and $\alpha$ is the interest rate semi-elasticity of money demand. $\gamma>0$ and $\alpha>0$. Similarly, assume the following equation also exists in foreign money markets:

$$
m_{t}^{f}=p_{t}^{f}+\gamma_{t}^{f}-\alpha i_{t}^{f}+v_{m t}^{f}
$$

Variables with the superscript " $f$ " represent foreign countries, and the rest follow the definition above. Since the nominal exchange rate is the purchasing power parity (PPP) plus the real exchange rate $x_{t}$, it can be expressed as:

$$
s_{t}=p_{t}-p_{t}^{f}+x_{t}(3)
$$

In the financial market, the interest parity relationship is:

$$
s_{t+1}^{e}-s_{t}=i_{t}-i_{t}^{f}+\rho_{t}
$$

In the above equation, the superscript " $e$ " means an expected value. $\rho_{t}$ can be interpreted as the risk premium or the expectation error. We can subtract Equation (1) with Equation (2) and apply equations (3) and (4) to derive the following equation:

$$
s_{t}=\left(m_{t}-m_{t}^{f}\right) /(1+\alpha)-\gamma\left(y_{t}-y_{t}^{f}\right) /(1+\alpha)+\alpha s_{t+1}^{e} /(1+\alpha)+\mu_{t}(5)
$$

Equation (5) is the money income model for exchange rates. The fundamentals which can be observed are $\left(m_{t}-m_{t}^{f}\right)$ and $\left(y_{t}-y_{t}^{f}\right)$; the fundamentals which cannot be observed are $s_{t+1}^{e}$ and $\mu_{t}$, where $\mu_{t}=$ $\left[\alpha \rho_{t}+\left(v_{m t}-v_{m t}^{f}\right)\right] /(1+\alpha)$ is the random shock. In the following task, we use the constant and error terms to capture $s_{t+1}^{e}$ and $\mu_{t}$. Equation (5) shows that when the domestic money supply increases relatively higher than in foreign 
countries, it will cause the depreciation of the home currency. When the increase in domestic output is relatively higher than in foreign countries, the quantity of imports in the home country goes up and causes the corresponding appreciation of currency.

\subsection{Taylor rule model}

Assume the home country is a small and open economy. If the central bank interferes by applying the interest rate rule (see Taylor, 1993; Engel and West, 2004, 2005), then the interest rate of the home country can be expressed as:

$$
i_{t}=\beta_{0}\left(s_{t}-\bar{s}_{t}\right)+\beta_{1} y_{t}^{g}+\beta_{2} \pi_{t}+w_{t}
$$

Where $\bar{s}_{t}$ is the target exchange rate; $y_{t}^{g}$ is the output gap; $\pi_{t}=p_{t}-p_{t-1}$ is the inflation rate; $w_{t}$ is the random shock, which includes some missing variables. $\beta_{0}>0$ in equation (6) means that the goal of the monetary authority is to keep the currency stable; therefore, when the exchange rate is higher than the target, then the monetary authority increases the interest rate to attract capital inflow and causes the appreciation of currency. On the contrary, when the exchange rate is lower than the target, then the interest rate is lowered to reduce the capital inflow or increase the capital outflow, which causes the depreciation of the currency. $\beta_{1}>0$ and $\beta_{2}>1$ indicate that the monetary authority adopts the "leaning against the wind" measure when the economy is overheating or inflation is too high (see Taylor, 1999; Aklan and Nargelecekenler, 2008).

Assume the monetary authority sets the target exchange rate to be the rate under PPP; $s_{t}=p_{t}-p_{t}^{f}$; combined with equation (4) we will get:

$$
s_{t}=\left[i_{t}^{f}+\beta_{0}\left(p_{t}-p_{t}^{f}\right)-\beta_{1} y_{t}^{g}-\beta_{2} \pi_{t}\right] /\left(1+\beta_{0}\right)+s_{t+1}^{e} /\left(1+\beta_{0}\right)+\varepsilon_{t}(7)
$$

Equation (7) is the exchange rate model based on the interest rate rule. Observable fundamentals include $i_{t}^{f}$, $\left(p_{t}-p_{t}^{f}\right), y_{t}^{g}$ and $\pi_{t}$. Unobservable shocks are $s_{t+1}^{e}$ and $\varepsilon_{t}=-\rho_{t}-w_{t}$. We also use the constant and the error term to capture $s_{t+1}^{e}$ and $\varepsilon_{t}$. The exchange rate model based on the interest rate rule implies that, when the domestic interest rate goes up, given the interest rate parity theory, capital outflow will increase, causing the depreciation of currency. When domestic prices increase relatively higher than foreign prices do, the relative purchasing power of the domestic currency drops, causing the depreciation of the exchange rate. When the economy or inflation is overheating ( $y_{t}^{g}>0$ or $\pi>0$ ), the monetary authority raises the interest rate in response. However, the rising in the domestic interest rate attracts capital inflow and causes the appreciation of currency.

\section{Empirical model and results}

\subsection{Data sources}

The data selected in this study is monthly data ranging from 1992Q1 to 2010Q1. The top sixteen trade partners of Taiwan are selected. Due to the lack of data sources, China, Indonesia and Singapore are excluded from the list. (Note 1) Therefore, only thirteen countries are used in the model, including the United States, the United Kingdom, Japan, Korea, Germany, France, Hong Kong, Canada, Australia, Holland, Malaysia, Philippines and Thailand. The exchange rate is defined as the New Taiwan dollars per unit of foreign currency. The Taiwan-U.S. exchange rate is from the Directorate General of Budget, Accounting and Statistics, Executive Yuan (DGBAS); the exchange rates of other Taiwan's trade partners are from the IFS database of the IMF (line rf). Bilateral exchange rates between Taiwan and the trade partners are calculated from the cross rates.

The data of the following variables are either from DGBAS or IMF-IFS. For interest rates, we use money market rates from the IFS (line 60b); for the price level, we use consumer price index (CPI, line 64); output data is the GDP (line 99b). M2 is used to measure the variable of money supply. For Hong Kong, Korea, Australia, Philippines and Thailand, M2 is calculated from the sum of lines 34 and 35; for the UK, M2 is line 351; for Canada, France, Germany, Japan, Malaysia, Holland, and the U.S., M2 is line 59.

The units of measurement in GDP and M2 are billions. The value of each foreign country's GDP is in New Taiwan dollars. Data of GDP, M2 and CPI are seasonally adjusted. All variables presented in logarithm forms excluding interest rates. Taiwan's output gap is estimated by Hodrick-Prescott Filter. We use the trade volume between Taiwan and each trade partner to measure the mutual dependency and set three currency baskets according to the order of trade weights. In the following sections, we make the empirical analysis in four different cases. Case 1 is the traditional method using Taiwan-U.S. exchange rate. Case 2 to case 4 use the multilateral exchange rates. In case 2, the multilateral exchange rate is constructed by three trade partners of Japan, the U.S. and Hong Kong. Other than the countries in case 2, Korea, Germany and Malaysia are added in case 3. Case 4 includes all the trade partners selected in this paper. Related information of these cases is listed in Table 1.

\subsection{Cointegration Tests}

According to Section 3, the exchange rate model can be expressed by equations (5) and (7). Based on Equation (5), 
the regression is expressed as follows:

$$
s_{t}=\delta_{0}+\delta_{1}\left(m_{t}-m_{t}^{f}\right)+\delta_{2}\left(y_{t}-y_{t}^{f}\right)+\eta_{t},(8)
$$

where $\delta_{0}$ is the constant term. $\delta_{1}$ and $\delta_{2}$ are regression coefficients. According to the theory, $\delta_{1}>0$ and $\delta_{2}<0 . \quad \eta_{t}$ is the white noise. $s_{t}$ is the Taiwan-U.S. bilateral exchange rate. Therefore, only the U.S. fundamentals are the related foreign variables. If studying the multilateral exchange rate, then the nominal effective exchange rate and the exchange rate model in Equation (5) will form the regression model as below:

$$
s_{t}^{w}=\delta_{o}^{w}+\delta_{1}^{w}\left(m_{t}-m_{t}^{f w}\right)+\delta_{2}^{\prime}\left(y_{t}-y_{t}^{f w}\right)+\eta_{t}^{w},
$$

where

$s_{t}^{w}=\sum_{i=1}^{n} s_{t}^{i} w_{t}^{i}$

$s_{t}^{i}$ is the bilateral exchange rate (in natural $\log$ form) for Taiwan and the $i$-th trade partner; $w_{t}^{i}$ is the trade weight for Taiwan and the $i$-th trade partner in period $t ; n$ is the number of trade partners in the currency basket; $\sum_{i=1}^{n} w_{t}^{i}=1$ ( Howitt, 1986; Weymark, 1995). Equation (8)' is the exchange rate model after considering the multilateral exchange rate. Variables with the superscript " $w$ " means variables with the trade weighted average. $s_{t}^{w}$ is the multilateral exchange rate; $m_{t}^{f w}$ and $y_{t}^{f w}$ are the trade weighted averages of foreign money supply and output. In other words, we employ trade dependency to measure the correlation between the economic fundamentals in Taiwan and all trade partners. The economic fundamentals of countries with higher trade weights have more impact on Taiwan (Weymark, 1995). Similar to Equation (8), Equation (8) ${ }^{\prime}$ requires the regression coefficient $\delta_{1}^{w}>0$ and $\delta_{2}^{w}<0 . \eta_{t}^{w}$ is the white noise.

Similarly, we design the following regression for Equation (7):

$$
s_{t}=\theta_{0}+\theta_{1} i_{t}^{f}+\theta_{2}\left(p_{t}-p_{t}^{f}\right)+\theta_{3} y_{t}^{g}+\theta_{4} \pi_{t}+\varphi_{t},
$$

In Equation (9), $\theta_{0}$ is the constant term. $\theta_{1}, \theta_{2}, \theta_{3}$, and $\theta_{4}$ are the regression coefficients. According to the theoretical model, we expect that $\theta_{1}>0, \theta_{2}>0, \theta_{3}<0$, and $\theta_{4}<0 . \varphi_{t}$ represents the white noise. Incorporating the concept of multilateral exchange rate in Equation (7), the regression model is:

$$
s_{t}^{w}=\theta_{0}^{w}+\theta_{1}^{w} i_{t}^{f w}+\theta_{2}^{w}\left(p_{t}-p_{t}^{f w}\right)+\theta_{3}^{w} y_{t}^{g}+\theta_{4}^{w} \pi_{t}+\varphi_{t}^{w} .
$$

Similarly, Equation $(9)^{\prime}$ calculates the foreign interest rates and foreign prices according to the trade weighted average ( $i_{t}^{f w}$ and $p_{t}^{f w}$, respectively) to measure the effect of trading partners on Taiwan; its implication is similar to Equation (8)'. As for the regression coefficients, we require $\theta_{1}^{w}>0, \theta_{2}^{w}>0, \theta_{3}^{w}<0$, and $\theta_{4}^{w}<0$. Assume $\varphi_{t}^{w}$ is the white noise.

Since most macroeconomic variables are non-stationary, it is difficult to apply the theoretical model in empirical studies. However, Davidson et al., (1978) stressed that the theoretical economic model displays the long-term equilibrium between variables; while the actual economic data are not generated in equilibrium (but gradually adjusted to the equilibrium). Therefore, cointegration analysis can help estimate the long-term equilibrium of a time series and verify the empirical feasibility of the exchange rate model. As a result, we follow the concepts in Davidson et al., (1978) and apply the cointegration analysis to test the empirical feasibility of the exchange rate model on the data in Taiwan.

Before proceeding with the estimation, we concerned ourselves with the time series characteristics of the data. Firstly, we needed to identify the integration order of the data. If the time series data exist in different integration orders, then cointegration does not exist; if the data have the same cointegration order, then we can estimate the long-term equilibrium in the next step (Engle and Granger, 1987).

Table 2 summarizes the unit root test statistics of all relevant macroeconomic variables. The number in the parentheses are $p$-value. We set the augmented Dicky-Fuller test (ADF test) to include the constant term and the time trend (with four lags). Panel A in Table 2 shows the unit root test results for the level of each macroeconomic variable. The test results indicate that at the $10 \%$ significance level, we cannot reject the null hypothesis that the unit root exists in the macroeconomic variables in all cases. As a result, all the standardized variable values are non-stationary series ( $y_{t}^{g}$ measures the output gap in Taiwan; therefore, it is the same variable under all cases). In panel B of Table 2, the unit root test for first order difference show that these variables are all significant at a $5 \%$ level, thus we can reject the null hypothesis that the unit root exists (most of them are significant at the $1 \%$ level). Therefore, the variables in the study are integration of order 1.

According to the I (1) characteristics of the macroeconomic variables in Equations (8), (8)', (9), and (9)', we found that it is difficult to interpret the exchange rates through economic fundamentals. If we are hasty in adopting the above regression analysis as the conclusion, a biased estimation or a spurious regression might result. The 
cointegration application proposed in Engle and Granger (1987) provides another analysis for non-stationary series. They suggested that if there is a linear combination that can transform the non-stationary variables to a stationary series, then the linear combination is called the cointegration. It also suggests the long-term equilibrium between explained variables and explanatory variables. As a result, if we can find the cointegration for equations (8), (8)', (9), and $(9)^{\prime}$, then we can successfully prove the theoretical long-term equilibrium of exchange rates and economic fundamentals in Taiwan.

We adopted the two-stage cointegration analysis in Engle and Granger (1987) below. First, the regression analysis was applied to equations (8), (8)', (9), and (9)' . Next, we applied the unit-root test on the residuals. If the residuals are a stationary series, it implies that cointegration exists between exchange rates and fundamental variables. The cointegration vector is the regression coefficient and the regression is feasible.

Conversely, if the residuals are non-stationary, the long-term equilibrium does not exist for the exchange rates and fundamental variables, and the regression analysis yields biased results. The results of the regression analysis for Equations (8), (8)', (9), and (9)' are summarized in Table 3 and Table 4.

Table 3 shows the results of the regression analysis for the money-income exchange rate model. Case 1 in panel A only focuses on the Taiwan-U.S. bilateral exchange rate model. Since the residuals are a non-stationary, even though the signs of the regression coefficients are both consistent with the theoretical requirements and significant, spurious relationship of no cointegration was estimated. Case 2 in panel B considers the multilateral exchange rates and fundamental variables of the top three trade partners; the residuals are also non-stationary. The signs of the regression coefficients are not consistent with the theoretical requirements; therefore, the estimation is biased. Panels $\mathrm{C}$ and $\mathrm{D}$ show that, as the multilateral exchange rates and fundamentals become more comprehensive (as in the estimations in cases 3 and 4), the null hypothesis that the unit root exists in residuals is rejected at the $5 \%$ level. The series is stationary. In other words, in these two cases, we found the long-term equilibrium between multilateral exchange rates and fundamental variables. The signs of the coefficients are not only consistent with the theoretical requirements, but are also highly significant (except for the regression coefficient $m_{t}-m_{t}^{f w}$ in panel $\mathrm{C}$, all other coefficients in panels $\mathrm{C}$ and $\mathrm{D}$ are significant at the $1 \%$ level). Therefore, the results of Table 3 are consistent with our expectations. If we control for more information and build comprehensive multilateral exchange rates and fundamentals, we can find the link between exchange rate model theory and the empirical data.

Table 4 shows the results of the regression analysis for the exchange rate model based on the interest rate rule. Similarly, we summarize the regression results of Equations (9) and (9)' in panels A to D by different cases. In Table 4, panels $\mathrm{A}$ and $\mathrm{B}$ suggest that the residuals in cases 1 and 2 are a non-stationary series; therefore the estimation is biased and the regression coefficients are meaningless. Panel $\mathrm{C}$ in Table 4 shows that under case 3 , the residuals are significant at the $5 \%$ level and stationary. The signs of the regression coefficients are consistent with the theoretical prediction (only $y_{t}^{g}$ is significant at the $10 \%$ level while the rest are all significant at the $5 \%$ level).

Similarly, panel D in Table 4 suggests that under case 4 , there is a stable equilibrium between the multilateral exchange rates and fundamental variables. The coefficient for $y_{t}^{g}$ is insignificant in case 4, suggesting it might be related to the measurement error of the macroeconomic data. Restricted by the available data and sample period, we excluded China, Singapore and Indonesia from the currency basket. These three countries are the third, sixth, and tenth largest trading partners of Taiwan. In the future, if we can collect more data and extend the sample period, we might be able to obtain a more precise estimation. Still, the above results are consistent with our estimation. The comprehensive constructs for multilateral exchange rate and fundamental variables improve the more empirically correlation of exchange rate model based on the interest rate rule.

\subsection{Granger causality Tests}

According to the asset-pricing exchange rate model, exchange rates can be expressed as the linear combination of the present value of current and expected future fundamental variables. Engel and West $(2004,2005)$ pointed out that if exchange rates can be displayed in the asset-pricing form, then their short-term fluctuation is no doubt the reflection of changes in future expectation. Market information reflects the future expectation for the fundamentals; therefore, the fluctuation in exchange rates is likely to help predict changes in fundamentals. Since the cointegration relationships between exchange rates and fundamental variables imply long-run equilibrium in theory, and the actual economic data are not generated in equilibrium, if the short-term exchange rate fluctuations can Granger-cause changes in fundamental variables (but not vice versa), then more comprehensive evidence improving the empirical credibility of the exchange rate model exist.

In order to present the money-income exchange rate model in Equation (5) in the form of asset-pricing, let $s_{t+1}^{e}=E_{t} s_{t+1}$, where $E_{t}$ is the rational expectation on economic variables in period $t$. By applying the 
law of iterated expectations and no-bubbles condition, we rewrite Equation (5) in the following form: (Note 2)

$$
s_{t}=(1+\alpha)^{-1} \sum_{j=0}^{\infty} \alpha^{j}(1+\alpha)^{-j} E_{t}\left[\left(m_{t+j}-m_{t+j}^{f}\right)-\gamma\left(y_{t+j}-y_{t+j}^{f}\right)\right]+\mu_{t}(10)
$$

Equation (10) shows that the exchange rate can be expressed as the sum of the present value of current and expected future domestic monetary aggregate and output, relative to that of foreign nations. $\alpha /(1+\alpha)>0$ is the discount factor, which is close to 1 based on previous studies. (Note 3$)$ Similarly, we rewrite Equation (7) as:

$$
s_{t}=\left(1+\beta_{0}\right)^{-1} \sum_{j=0}^{\infty}\left(1+\beta_{0}\right)^{-j} E_{t}\left[i_{t+j}^{f}+\beta_{0}\left(p_{t+j}-p_{t+j}^{f}\right)-\beta_{1} y_{t+j}^{g}-\beta_{2} \pi_{t+j}\right]+\varepsilon_{t}(11)
$$

Equation (11) also presents the exchange rate model in asset-pricing form. $1 /\left(1+\beta_{0}\right)>0$; it is also close to 1 empirically (see Clarida et al., 1998). (Note 4) According to the exchange rate model based on the Taylor rule, the exchange rate can be expressed as the sum of the present value of the current and expected future foreign interest rates, and relative domestic/foreign prices, output gap, and the inflation rate. From the perspective of the asset-pricing exchange rate model, fluctuations in the exchange rate can cause changes in the future fundamentals (but not vice versa). Let $f_{t}$ represent the fundamental variables. According to Equation (10) and (11), $f_{t}$ includes $m_{t}-m_{t}^{f}, y_{t}-y_{t}^{f}, i_{t}^{f}, p_{t}-p_{t}^{f}, y_{t}^{g}$, and $\pi_{t}$. After considering the multilateral exchange rates, the foreign variables are replaced by $m_{t}^{f w}, y_{t}^{f w}$, and $i_{t}^{f w}$. The Granger causality tests for changes in exchange rates and fundamentals are shown in Table 5.

Table 5 shows results of the Granger causality test in four cases. In the testing process, the null hypotheses are " $\Delta s_{t}$ cannot Granger-cause $\Delta f_{t}$ " and " $\Delta f_{t}$ cannot Granger-cause $\Delta s_{t}$ ". In case 1, we cannot find any causality between fluctuations in the Taiwan-U.S. bilateral exchange rate and changes in the fundamentals. The result is consistent with Chou and Tseng (2008). However, when we extend the subject to the multilateral exchange rate, tests in cases 2 to 4 show that at the $10 \%$ significance level, 10 out of the 18 tests reject the null hypothesis that " $\Delta s_{t}$ cannot Granger-cause $\Delta f_{t}$ ". Under the other null hypothesis, only 2 out of 18 tests reject the null hypothesis that " $\Delta f_{t}$ cannot Granger-cause $\Delta s_{t}$ ".

If we carefully compare cases 3 and 4, the multilateral exchange rates of the top 6 and top 13 trade partners, under the same $10 \%$ significance level, $67 \%$ reject the null hypothesis that " $\Delta s_{t}$ cannot Granger-cause $\Delta f_{t}$ ", while only $8 \%$ reject the null hypothesis " $\Delta f_{t}$ cannot Granger-cause $\Delta s_{t}$. " Therefore, the significantly different results among cases 2 to 4 show that fluctuations in multilateral exchange rates do help predict changes in the fundamentals, especially regarding predictions on nominal variables such as $\Delta i_{t}^{f w}$ and $\Delta\left(p_{t}-p_{t}^{f w}\right)$. In conclusion, the Granger causality tests support our hypothesis that more comprehensive information compiled about a multilateral exchange rate can improve the empirical credibility of exchange rate models.

\section{Conclusion}

It has long been a puzzle in international finance that empirical correlation is hard to be proved between exchange rate and macroeconomic fundamental variables. Since exchange rates follow random walks, it cannot be predicted by fundamentals empirically. This fact also exists in Taiwan when studying the Taiwan-U.S. exchange rate. As a result, related studies indicate that the Taiwan-U.S. exchange rate might be dominated by other factors that can not be explained. Instead of using the Taiwan-U.S. exchange rate, we construct multilateral exchange rates to discuss this issue. By compiling a nominal effective exchange rate based on the bilateral trade volume of Taiwan with its major trading partners to measure mutual dependency, and applying it to study the relationship between the exchange rate and market fundamentals, we find that the correlation between exchange rates and fundamentals cannot be proved if only Taiwan-U.S. bilateral exchange rate is considered. However, as the number of countries in the currency basket increased and a more comprehensive multilateral exchange rate was constructed, we were able to not only find cointegration relationships between exchange rates and fundamentals, but also verify the empirical reliability of the exchange rate models. Our results show that the multilateral exchange rates provide more information and improve the explanatory power of traditional exchange rate models. It also helps explain the correlation between the macroeconomics of Taiwan and other countries.

\section{References}

Aklan, N. A., \& Nargelecekenler, M. (2008). Taylor Rule in Practice: Evidence from Turkey, International Atlantic Economic Society, 14, 156-166, http://dx.doi.org/10.1007/s11294-008-9148-9

Baharumshah, A. Z., MacDoonald, R., \& Mohd, S. H. (2010). Exchange Rates in Singapore and Malaysia: Are They Driven by the Same Fundamentals? Malaysian Journal of Economic Studies, 47, 123-141.

Chen, J. H. (2006). EER Compilation for the Three Major Currencies, Economic \&Research, 6, 1-32. 
Bilson, J. F. O. (1978). The Monetary Approach to the Exchange Rate: Some Empirical Evidence, IMF Staff Papers, 25, 48-75.

Cheung, Y. W., M. D. Chinn \& Pascual, A. G. (2005), Empirical Exchange Rate Models of the Nineties: Are Any Fit to Survive? Journal of International Money and Finance, 24, 1150-1175, http://dx.doi.org/10.1016/j.jimonfin.2005.08.002

Chinn, M. D., \& Meese, R. A. (1995). Banking on Currency Forecasts: How Predictable Is Change in Money? Journal of International Economics, 38, 161-78, http://dx.doi.org/doi:10.1016/0022-1996(94)01334-O

Chinn, M. D. (2000a). Before the Fall: Were East Asian Currencies Overvalued? Emerging Markets Review, 2, 101-126, http://dx.doi.org/10.1016/S1566-0141(00)00008-X

Chinn, M. D. (2000b). Three Measures of East Asian Currency Overvaluation, Contemporary Economic Policy, 18, 205-214, http://dx.doi.org/10.1111/j.1465-7287.2000.tb00018.x

Chou, K. W., \& Tseng, Y. H. (2008). The Prediction Performance for Macroeconomic Market Fundamentals: An Empirical Analysis of Exchange Rate Models for Taiwan and Other Six Countries, Taiwan Economic Forum, 6, 36-65.

Clarida, R., Gali J., \& Gertler, M. (1998). Monetary Policy Rules in Practice: Some International Evidence, European Economic Review, 42, 1033-1067, http://dx.doi.org/10.1016/S0014-2921(98)00016-6

Davidson, J. E. H., Hendry, D. F., Srba, F., \& Yeo, S. (1978). Econometric Modeling of the Aggregate Time-Series Relationship between Consumer's Expenditure and Income in the United Kingdom, The Economic Journal, 88, 661-692.

Engel, C., \& West, K. D. (2004). Accounting for Exchange-Rate Variability in Present-Value Models When the Discount Factor Is Near 1, The American Economic Review, 94, 119-125.

Engel, C., \& West, K. D. (2005). Exchange Rates and Fundamentals, Journal of Political Economy, 113, 485-517.

Engle, R. F., \& Granger, C. W. J. (1987). Co-Integration and Error Correction: Representation, Estimation, and Testing, Econometrica, 55, 251-276.

Frankel, J. A. (1979). On the Mark: A Theory of Floating Exchange Rates Based on Real Interest Differentials, American Economic Review, 69, 610-622.

Goldberg, L., \& Tracy, J. (1999). Exchange Rates and Employment Instability: Evidence from Matched CPS Data, American Economic Review, 89, 204-210.

Howitt, P. (1986), Money Policy in Transition: A Study of Bank of Canada Policy 1982-85, C.D. Howe Institute, Toronto.

Husted, S., \& MacDonald, R. (1999). The Asian Currency Crash: Were Badly Driven Fundamentals to Blame? Journal of Asian Economics, 10, 537-550, http://dx.doi.org/10.1016/S1049-0078(00)00031-2

Krungman, P. R. and M. Obstfeld (2009), International Economics: Theory and Policy, (8 ${ }^{\text {th }}$ ed.) Edition, Pearson.

MacDonald, R., \& Taylor, M. P. (1993). The Monetary Approach to the Exchange Rate: Rational Expectations, Long-run Equilibrium and Forecasting Short-run Dynamics and How to Beat a Random Walk, Journal of International Money and Finance, 13, 276-290, http://dx.doi.org/10.1016/0261-5606(94)90029-9

Mark, N. C. (1995). Exchange Rates and Fundamentals: Evidence on Long Horizon Predictability, American Economic Review, 85, 201-218.

Mark, N. C., \& Sul, D. (2001). Nominal Exchange Rates and Monetary Fundamentals: Evidence from a Small Post-Bretton Woods Sample, Journal of International Economics, 53, 29-52, http://dx.doi.org/10.1016/S0022-1996(00)00052-0

McNown, R., \& Wallace, M. S. (1994). Cointegration Tests of the Monetary Exchange Rate Model for Three High Inflation Economics, Journal of Money, Credit, and Banking, 26, 396-41.

Meese, R. A., \& Rogoff, K. S. (1983a). Empirical Exchange Rate Models of the Seventiey: Do They Fit Out of Sample? Journal of International Economics, 14, 3-24, http://dx.doi.org/10.1016/0022-1996(83)90017-X

Meese, R. A., \& Rogoff, K. S. (1983b). The Out of Sample Failure of Empirical Exchange Models, In Exchange Rates and International Macroeconomics, edited by Jacob A. Frenkel. Chicago: Univ. Chicago Press (for NBER).

Moosa, I. A. (1994). The Monetary Model of Exchange Rates Revisited, Applied Financial Economics, 26, 279-287, http://dx.doi.org/10.1080/758530894

Rhomberg, R. R. (1976). Indices of Effective Exchange Rates, IMF Staff Paper, 23, 88-112. 
Stock, J. H., \& Watson, M. W. (1993). A Simple Estimator of Cointegrating Vectors in Higher Order Integrated Systems, Econometrica, 61, 783-820, http://dx.doi.org/10.2307/2951763

Taylor, J. B. (1993). Discretion versus Policy Rules in Practice, Carnegie-Rochester Conference Series on Public Policy, 39, 195-214, http://dx.doi.org/10.1016/0167-2231(93)90009-L

Tsaur, T. W., Lai, C. C., Jung, C. W., Kuo, B. S., \& Tsay, W. J. (2002). Dynamic Analysis on Taiwan's Real Effective Exchange Rate Index, Taiwan Economic Forecast and Policy, 32, 93-130.

Tseng, Y. H. (2007). An Empirical Study about Real Effective Exchange Rates of New Taiwan Dollar, Taiwan Economic Forum, 5, 46-78.

Tseng, Y. H., \& Tsaur, T. W. (2008). A Practical Study on Constructing Taiwan's Real Effective Exchange Rates Index: Prediction Performance for Combination of Currency Baskets and Weights Choices, Taiwan Economic Forecast and Policy, 39, 97-143.

Weymark, D. N. (1995). Estimating Exchange Market Pressure and the Degree of Exchange Market Intervention for Canada, Journal of International Economics, 39, 273-295, http://dx.doi.org/10.1016/0022-1996(95)01389-4

\section{Notes}

Note 1. Data of GDP in China, Singapore begin only from 1999Q2 and 2003Q1; information of M2 in Indonesia only can be traced back to 1995Q. Because of the small sample sizes, we exclude these countries in the study.

Note 2. No-bubbles condition is $\lim _{j \rightarrow \infty} E_{t} s_{t+j}=0$.

Note 3. Based on quarterly data, $\alpha$ was estimated about 60 in Blison (1978), 29 in Frankel (1979) and 40 in Stock and Watson (1993). In other words, the discount factor in Equation (10) is about 0.97-0.98.

Note 4. Clardia et al. (1998) estimated that $1 /\left(1+\beta_{0}\right)$ is about 0.98-0.99.

Table 1. Countries discussed in the multilateral exchange rate

\begin{tabular}{llc}
\hline & Countries in the currency basket & $\begin{array}{c}\text { The proportion in Taiwan's trade } \\
\text { volume (\%) }\end{array}$ \\
\hline Case 1 & US & 14.37 \\
Case 2 & Japan, US, Hong Kong & 39.35 \\
Case 3 & Japan, US, Hong Kong, Korea, Germany, Malaysia & 49.75 \\
Case 4 & Japan, US, Hong Kong, Korea, Germany, Malaysia, Australia, & 60.39 \\
& Philippines, Holland, Thailand, United Kingdom, France, Canada & \\
\hline
\end{tabular}

1. The proportions in Taiwan's trade volume are based on the average annual data of 2000-2009.

2. Data source: sorted by authors from DGBAS.

Table 2. Unit Root Tests

\begin{tabular}{|c|c|c|c|c|c|c|}
\hline Variables & $s_{t}\left(s_{t}^{w}\right)$ & $m_{t}-m_{t}^{f}\left(m_{t}^{f w}\right)$ & $y_{t}-y_{t}^{f}\left(y_{t}^{f w}\right)$ & $i_{t}^{f}\left(i_{t}^{f w}\right)$ & $p_{t}-p_{t}^{f}\left(p_{t}^{f w}\right)$ & $y_{t}^{g}$ \\
\hline \multicolumn{7}{|c|}{ Panel A: Level } \\
\hline Case 1: & $\begin{array}{l}-1.358 \\
(0.864)\end{array}$ & $\begin{array}{l}-3.049 \\
(0.127)\end{array}$ & $\begin{array}{l}-1.980 \\
(0.601)\end{array}$ & $\begin{array}{l}-2.752 \\
(0.219)\end{array}$ & $\begin{array}{l}-3.194 \\
(0.094)\end{array}$ & $\begin{array}{l}-2.694 \\
(0.242)\end{array}$ \\
\hline Case 2: & $\begin{array}{l}-2.788 \\
(0.206)\end{array}$ & $\begin{array}{l}-3.296 \\
(0.075)\end{array}$ & $\begin{array}{l}-3.017 \\
(0.135)\end{array}$ & $\begin{array}{c}-2.783 \\
(0.208)\end{array}$ & $\begin{array}{l}-3.180 \\
(0.097)\end{array}$ & $\begin{array}{l}-2.694 \\
(0.242)\end{array}$ \\
\hline Case 3: & $\begin{array}{l}-2.988 \\
(0.143)\end{array}$ & $\begin{array}{l}-3.108 \\
(0.112)\end{array}$ & $\begin{array}{l}-2.645 \\
(0.262)\end{array}$ & $\begin{array}{l}-2.429 \\
(0.361)\end{array}$ & $\begin{array}{l}-4.384 \\
(0.004)\end{array}$ & $\begin{array}{l}-2.694 \\
(0.242)\end{array}$ \\
\hline Case 4: & $\begin{array}{c}-2.971 \\
(0.147) \\
\end{array}$ & $\begin{array}{l}-2.558 \\
(0.300) \\
\end{array}$ & $\begin{array}{l}-2.127 \\
(0.521)\end{array}$ & $\begin{array}{l}-2.370 \\
(0.391)\end{array}$ & $\begin{array}{l}-3.650 \\
(0.032)\end{array}$ & $\begin{array}{l}-2.694 \\
(0.242)\end{array}$ \\
\hline \multicolumn{7}{|c|}{ Panel B: First order difference } \\
\hline Case 1: & $\begin{array}{l}-6.017 \\
(0.000)\end{array}$ & $\begin{array}{l}-2.974 \\
(0.004)\end{array}$ & $\begin{array}{c}-3.958 \\
(0.015)\end{array}$ & $\begin{array}{l}-3.696 \\
(0.030)\end{array}$ & $\begin{array}{c}-2.991 \\
(0.041)\end{array}$ & $\begin{array}{l}-5.532 \\
(0.000)\end{array}$ \\
\hline Case 2: & $\begin{array}{l}-3.022 \\
(0.003)\end{array}$ & $\begin{array}{l}-4.175 \\
(0.008)\end{array}$ & $\begin{array}{l}-4.322 \\
(0.005)\end{array}$ & $\begin{array}{l}-3.763 \\
(0.025)\end{array}$ & $\begin{array}{c}-5.110 \\
(0.000)\end{array}$ & $\begin{array}{l}-5.532 \\
(0.000)\end{array}$ \\
\hline Case 3: & $\begin{array}{l}-2.965 \\
(0.044)\end{array}$ & $\begin{array}{l}-4.517 \\
(0.003)\end{array}$ & $\begin{array}{l}-4.703 \\
(0.002)\end{array}$ & $\begin{array}{l}-3.789 \\
(0.023)\end{array}$ & $\begin{array}{l}-4.976 \\
(0.001)\end{array}$ & $\begin{array}{l}-5.532 \\
(0.000)\end{array}$ \\
\hline Case 4: & $\begin{array}{c}-3.149 \\
(0.028)\end{array}$ & $\begin{array}{c}-4.503 \\
(0.003)\end{array}$ & $\begin{array}{c}4.779 \\
(0.001)\end{array}$ & $\begin{array}{l}-4.085 \\
(0.011)\end{array}$ & $\begin{array}{c}-4.928 \\
(0.001)\end{array}$ & $\begin{array}{l}-5.532 \\
(0.000)\end{array}$ \\
\hline
\end{tabular}

1. See the notes to Table 1 for definitions of cases 1-4. 
2. Variable definitions: $s_{t}$ is the nominal exchange rate (Taiwan as the home country). In other variables " $f$ " indicates the non-Taiwan variables and " $w$ " indicates weighted average. $m_{t}$ is the money supply after seasonally adjusted; $y_{t}$ is the real GDP after seasonally adjusted; $i_{t}$ denotes the interest rate; $p_{t}$ is the consumer price; $y_{t}^{g}$ is the output gap. All variables but interest rates are converted by taking logs.

3. The Augmented Dicky-Fuller test statistics ( $t$-statistics) are computed from fourth-order autoregression with a time trend included. The number in (.) is $p$-value.

4. Data are quarterly, spanning from 1992 Q1 to 2010 Q1.

5. Data source: DGBAS and IMF-IFS.

Table 3. Money-Income Exchange Rate Models

\begin{tabular}{|c|c|c|c|}
\hline \multirow{2}{*}{$\begin{array}{l}\text { Panel A: Case } 1 \\
\text { Explanatory variable: }\end{array}$} & & & \\
\hline & constant & $m_{t}-m_{t}^{f}$ & $y_{t}-y_{t}^{f}$ \\
\hline \multirow[t]{2}{*}{ Coefficient estimated: } & $\begin{array}{c}1.875 * * * \\
{[0.564]}\end{array}$ & $\begin{array}{c}0.340 * * * \\
{[0.074]}\end{array}$ & $\begin{array}{c}-0.957 * * * \\
{[0.060]}\end{array}$ \\
\hline & & & $R^{2}=0.802, \bar{R}^{2}=0.797$ \\
\hline $\begin{array}{l}\text { Residuals unit root test } \\
\text { (t-statistics): }\end{array}$ & -1.769 & & \\
\hline \multicolumn{4}{|l|}{ Panel B: Case 2} \\
\hline Explanatory Variable: & constant & $m_{t}-m_{t}^{f w}$ & $y_{t}-y_{t}^{f w}$ \\
\hline \multirow[t]{2}{*}{ Coefficient Estimated: } & $\begin{array}{l}3.704^{* *} \\
{[1.830]}\end{array}$ & $\begin{array}{c}0.365 \\
{[0.272]}\end{array}$ & $\begin{array}{c}-0.181 \\
{[0.194]}\end{array}$ \\
\hline & & & $R^{2}=0.608, \bar{R}^{2}=0.582$ \\
\hline $\begin{array}{l}\text { Residuals unit root test } \\
\text { (t-statistics): }\end{array}$ & -2.879 & & \\
\hline \multicolumn{4}{|l|}{ Panel C: Case 3} \\
\hline Explanatory Variable: & constant & $m_{t}-m_{t}^{f w}$ & $y_{t}-y_{t}^{f w}$ \\
\hline \multirow[t]{2}{*}{ Coefficient Estimated: } & $\begin{array}{l}4.679^{* *} \\
{[2.074]}\end{array}$ & $\begin{array}{c}0.809^{* *} \\
{[0.320]}\end{array}$ & $\begin{array}{c}-1.083^{* * *} \\
{[0.211]}\end{array}$ \\
\hline & & & $R^{2}=0.389, \quad \bar{R}^{2}=0.371$ \\
\hline $\begin{array}{l}\text { Residuals unit root test } \\
\text { (t-statistics): }\end{array}$ & $-2.061 * *$ & & \\
\hline \multicolumn{4}{|l|}{ Panel D: Case 4} \\
\hline Explanatory Variable: & constant & $m_{t}-m_{t}^{f w}$ & $y_{t}-y_{t}^{f w}$ \\
\hline \multirow[t]{2}{*}{ Coefficient Estimated: } & $\begin{array}{c}6.609 * * * \\
{[1.597]}\end{array}$ & $\begin{array}{c}0.981 * * * \\
{[0.248]}\end{array}$ & $\begin{array}{c}-0.926^{* * *} \\
{[0.1156]}\end{array}$ \\
\hline & & & $R^{2}=0.397, \bar{R}^{2}=0.380$ \\
\hline $\begin{array}{l}\text { Residuals unit root test } \\
\text { (t-statistics): }\end{array}$ & $-2.479 * *$ & & \\
\hline
\end{tabular}

1. The number in [.] under coefficient is standard deviation. ${ }^{* * *},{ }^{* *}$, and $*$ indicate that the coefficients are significant at the $1 \%, 5 \%$, and $10 \%$ levels.

2. The Augmented Dicky-Fuller test statistics ( $t$-statistics) for residuals are computed from fourth-order autoregression with a time trend included. $* * *, * *$, and * indicate that the null hypothesis of a unit root is rejected at the $1 \%, 5 \%$, and $10 \%$ significance levels.

3. See the notes to Table 2 for variable definitions. 
Table 4. Taylor Rule Exchange Rate Models

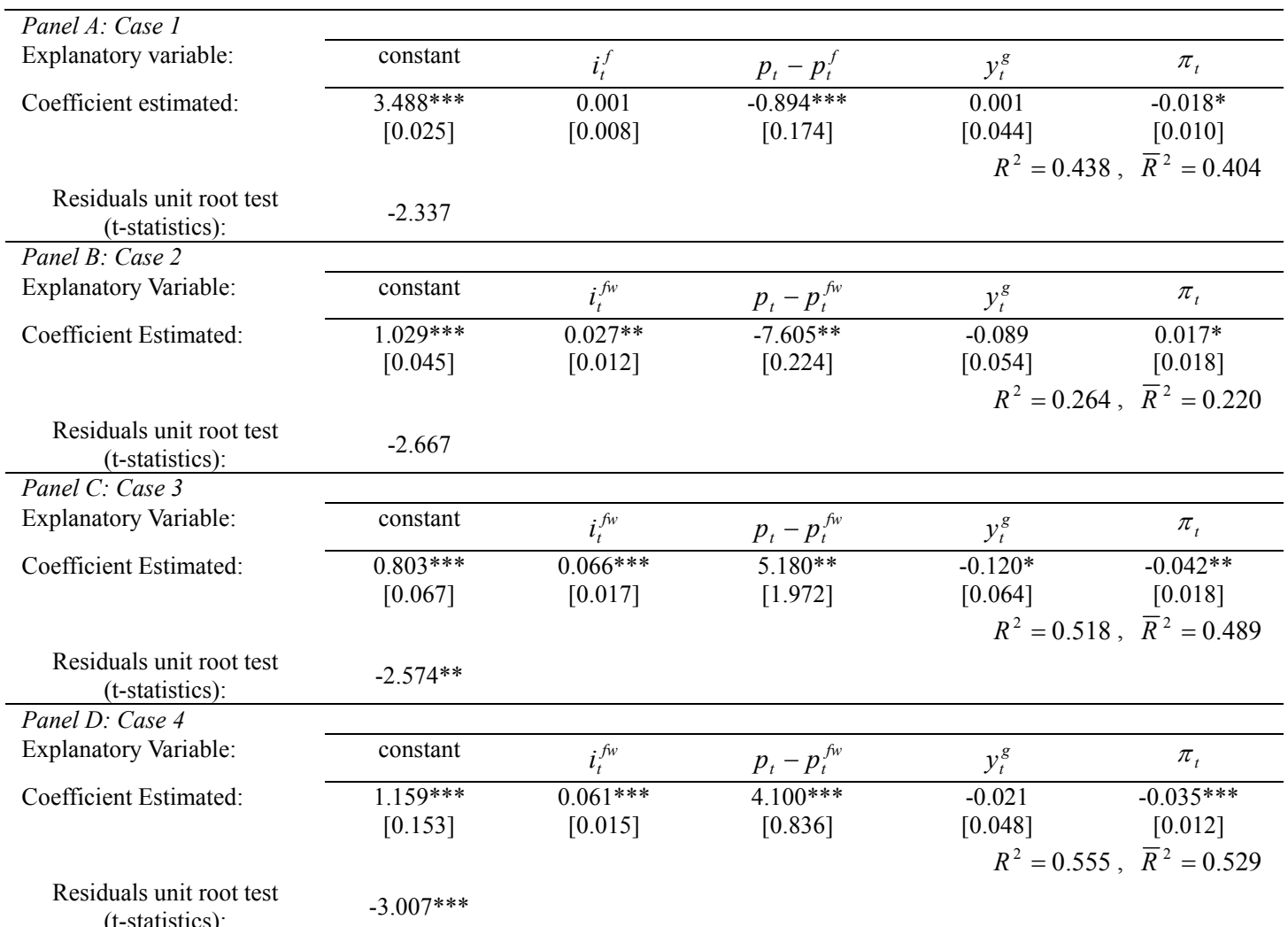

1. The number in [.] under coefficient is standard deviation. ***,**, and * indicate that the coefficients are significant at the $1 \%, 5 \%$, and $10 \%$ levels.

2. The Augmented Dicky-Fuller test statistics ( $t$-statistics) for residuals are computed from fourth-order autoregression with a time trend included. ***,**, and * indicate that the null hypothesis of a unit root is rejected at the $1 \%, 5 \%$, and $10 \%$ significance levels.

3. See the notes to Table 2 for variable definitions ( $\pi_{t}$ is the inflation rate in Taiwan).

Table 5. Granger Causality Tests

\begin{tabular}{|c|c|c|c|c|c|c|}
\hline \multicolumn{7}{|l|}{ Panel A. Case 1} \\
\hline & $\Delta\left(m_{t}-m_{t}^{f}\right)$ & $\Delta\left(y_{t}-y_{t}^{f}\right)$ & $\Delta i_{t}^{f}$ & $\Delta\left(p_{t}-p_{t}^{f}\right)$ & $\Delta y_{t}^{g}$ & $\pi_{t}$ \\
\hline$H_{O}: \Delta s_{t}$ Fails to cause $\Delta f_{t}$ & 0.201 & 0.803 & 0.667 & 0.966 & 1.337 & 0.745 \\
\hline$H_{O}: \Delta f_{t}$ Fails to cause $\Delta s_{t}$ & 0.785 & 0.948 & 0.739 & 0.732 & 0.929 & 0.509 \\
\hline \multicolumn{7}{|l|}{ Panel B: Case 2} \\
\hline & $\Delta\left(m_{t}-m_{t}^{f w}\right)$ & $\Delta\left(y_{t}-y_{t}^{f w}\right)$ & $\Delta i_{t}^{f w}$ & $\Delta\left(p_{t}-p_{t}^{f w}\right)$ & $\Delta y_{t}^{g}$ & $\pi_{t}$ \\
\hline$H_{O}: \Delta s_{t}^{w} \quad$ Fails to cause $\Delta f_{t}^{w}$ & $2.881^{*}$ & 0.341 & $5.208^{* * *}$ & $1.920^{*}$ & 1.415 & 0.351 \\
\hline$H_{O}: \Delta f_{t}^{w}$ Fails to cause $\Delta s_{t}^{w}$ & $2.779^{*}$ & 1.094 & 0.140 & 1.119 & 0.779 & 0.321 \\
\hline \multicolumn{7}{|l|}{ Panel C: Case 3} \\
\hline & $\Delta\left(m_{t}-m_{t}^{f w}\right)$ & $\Delta\left(y_{t}-y_{t}^{f w}\right)$ & $\Delta i_{t}^{f w}$ & $\Delta\left(p_{t}-p_{t}^{f w}\right)$ & $\Delta y_{t}^{g}$ & $\pi_{t}$ \\
\hline$H_{O}: \Delta s_{t}^{w} \quad$ Fails to cause $\Delta f_{t}^{w}$ & $2.811 *$ & 0.486 & $3.871 * *$ & $4.491 * * *$ & $4.117 * *$ & 0.478 \\
\hline$H_{O}: \Delta f_{t}^{w}$ Fails to cause $\Delta s_{t}^{w}$ & 1.993 & 1.834 & 0.335 & 1.039 & 0.926 & 0.222 \\
\hline \multicolumn{7}{|l|}{ Panel D: Case 4} \\
\hline & $\Delta\left(m_{t}-m_{t}^{f w}\right)$ & $\Delta\left(y_{t}-y_{t}^{f w}\right)$ & $\Delta i_{t}^{f w}$ & $\Delta\left(p_{t}-p_{t}^{f w}\right)$ & $\Delta y_{t}^{g}$ & $\pi_{t}$ \\
\hline$H_{O}: \Delta s_{t}^{w} \quad$ Fails to cause $\Delta f_{t}^{w}$ & $2.536^{*}$ & 0.756 & $3.003 *$ & $4.894 * * *$ & $2.295^{*}$ & 0.755 \\
\hline$H_{O}: \Delta f_{t}^{w}$ Fails to cause $\Delta s_{t}^{w}$ & 1.808 & $2.442 *$ & 0.830 & 0.589 & 1.001 & 0.070 \\
\hline
\end{tabular}

1. $F$-statistics are computed from fourth-order bivariate VAR system in $\left(\Delta s_{t}, \Delta f_{t}\right)^{\prime}$ and $\left(\Delta s_{t}^{w}, \Delta f_{t}^{w}\right)^{\prime} . * * *, * *$, and * indicate that the null hypothesis is rejected at the $1 \%, 5 \%$, and $10 \%$ significance levels.

2. See the notes to Table 2 for variable definitions. 